\title{
Integration of Information System Success Models to Explain End User Satisfaction of Debtor Information Systems
}

\section{Arif Hartono, Novia Permatasari, Ika Farida Ulfah and La Ode Sugianto}

Economic Faculty, Muhammadiyah University of Ponorogo

J1. Budi Utomo No.10, Siman, Ponorogo, 63471, Indonesia

\section{Info Article}

Keywords:

Information Quality; Information System Quality; Perceived Ease Of Use; End User Satisfaction; Perceived Usefulness.

ISSN (print) : 2598-7763 ISSN (online): 2598-7771

$\square$ Corresponding Author: La Ode Sugianto

Tel. /Fax. +6285257573713

E-mail:

laodesugianto@umpo.ac.id

\section{Abtract}

Acceptance Models by Davis (1988). This study integrates the information system quality variable, information quality variable, and end-user satisfaction variable from Information System Success. The population in this study were all employees user SID of the financial institution, the samples were 166 employees of finance institution. The sampling technique was nonprobability sampling with purposive sampling. The type of data was primary data by the method of questionnaire data collection. This research uses Structural Equation Model to analysis the method and analysis tool used was PLS. The results of this study show that information system quality significantly affects the perceived usefulness, information system quality significantly affects the perceived ease of use, information quality significantly affects the perceived usefulness, information quality significantly affects the perceived ease of use, information quality significantly affects the end-user satisfaction, perceived ease of use significantly affects the perceived usefulness, perceived usefulness significant affects the end-user satisfaction, and perceived ease of use significantly affects the end-user satisfaction. But, the examine the information quality didn't significantly affect end-user satisfaction.

Citation: Hartono, A., Permatasari, N., Ulfah, F., I., and Sugianto, O.L (2019). Integration of Information System Success Models to Explain End User Satisfaction of Debtor Information Systems. AFRE Accounting and Financial Review, 2 (1).

\begin{abstract}
Abstraks
Penelitian ini bertujuan untuk menguji penggunaan Sistem Informasi Debitur (SID) pada lembaga keuangan di bawah pengawasan Bank Indonesia Kantor Perwakilan Wilayah Kediri dengan menggunakan model Kesuksesan Sistem Informasi dari DeLone dan McLean (1992) dan model Penerimaan Teknologi dari Davis (1988). Penelitian ini mengintegrasi variabel kualitas sistem informasi, kualitas informasi dan kepuasan pengguna akhir dari model Kesuksesan Sistem. Populasi dalam penelitian ini adalah seluruh karyawan lembaga keuangan pengguna SID, sampel dalam penelitian ini sebanyak 166 karyawan lembaga keuangan. Teknik pengambilan sampel adalah nonprobability sampling dengan menggunakan metode purposive sampling. Jenis data yang digunakan adalah data primer dengan metode pengumpulan data kuesioner. Penelitian ini menggunakan metode analisis Structural Equation Model dengan alat uji analisis PLS. Hasil penelitian menunjukkan bahwa kualitas sistem informasi berpengaruh terhadap persepsi kegunaan, kualitas sistem informasi berpengaruh terhadap persepsi kemudahan menggunakan, kualitas informasi berpengaruh terhadap persepsi kegunaan, kualitas informasi berpengaruh terhadap persepsi kemudahan menggunakan, kualitas informasi berpengaruh terhadap kepuasan pengguna akhir, persepsi kemudahan menggunakan berpengaruh terhadap persepsi kegunaan, persepsi kegunaan berpengaruh terhadap kepuasan pengguna akhir, dan persepsi kemudahan mengggunakan berpengaruh terhadap kepuasan pengguna akhir. Namun, pada pengujian kualitas sistem informasi tidak berpengaruh terhadap kepuasan pengguna akhir
\end{abstract}

JEL Classification D83, L15

DOI: https://doi.org/10.26905/afr.v2i1.3260 


\section{INTRODUCTION}

The success in the implementation of digital information systems account the degree of acceptance by end-user satisfaction. So that the application of information systems should have a positive impact in improving the organization's business processes. Improved good information system infrastructure is expected that users can play a strategic role in improving user performance, thus impacting on the effectiveness of the organization being run. One banking information system infrastructure is vulnerable to an increase in the Debtor Information System (SID). Debtor Information System (SID) is a system that provides information about debtors in the form of processed debtor reports from creditors reported and received by Bank Indonesia. Excerpted from the pages accessed on okezone.com (2017) Bank Indonesia has issued a fee of $\operatorname{Rp} 650,000,000,000$ to build a Debtor Information System infrastructure and accommodate Constraints, namely the first one faced by a Debtor Information System is the accuracy of debtor data that has been reported to be less valid and complete. The second obstacle, the Debtor Information System is suspected of having errors in storing data information that is not in accordance with the actual conditions. So that there is a possibility that the Financial Services Authority (OJK) will take over SID by developing infrastructure through the Financial Information Service System (SLIK).

This research develops a success model of information systems developed by DeLone and McLean (1992), where researchers use variable quality information systems, information quality, and user satisfaction. Then the model is integrated with the Technology Acceptance Model developed by Davis (1989), where researchers use perceived usefulness and perceived ease of use. Offering information technology through internet services is currently felt to reduce costs, affect performance more efficiently, and have a higher degree of flexibility than manual processes. Information technology can facilitate the implementation of accounting information systems, so that users of accounting information systems can reflect the level of satisfaction of end users.

The satisfaction of end-user accounting information systems can be improved through perceptions of usability and perceived ease of use by reviewing the quality of information systems and the quality of information presented. End-user satisfaction shows an evaluation of the level of use of information systems that are used as a basis for decision making that impacts on productivity produced by individuals to gain competitive advantage (Doll and Torkzadeh, 1988). This illustrates that end-user satisfaction has an important role in the success of the SID used. Because the satisfaction of the end user knows how much the content level of information produced, the accuracy and timeliness of the SID is able to meet user needs. The success of information systems is identified from the factors of users who operate the system (Kim and McHaney, 2000). Users as a determinant of success in terms of information systems information systems quality level and quality of information (Hartono, 2007). The quality of the information system is a software information system technology by utilizing internet services that are used in data processing of customer transactions; The customer transaction data will produce quality information that can be set in the form of acceptance transaction deposits and lending (Kartika, Anton, and Adnanti, 2016). The quality of information is the user's perception of information produced by information systems (Istianingsih and Wijanto, 2008).

The quality of information systems and the quality of information arise as a result of user behavior on receiving information systems. Acceptance behavior is due to perceptions of usability and perceived ease of use (Adams, Nelson, and Todd, 1997). Usability perception is a perceived benefit of trust using information systems as a basis for business decision making (Santoso, 2012). The decision making on the basis of trust that by using the information system and rely on the information presented benefits for users because the users have perceived ease of use on the system. Wibowo, et al (2015) describes the perceived ease of use in the form of a trust ease of use of information systems and understand the information presented as a decision-making process.

This study is a replication of these studies to test the quality of information systems and quality information based on the perception of usefulness and perceived ease of use with each effect. Then the information system quality, information quality, perceived usefulness, perceived ease of use to show the end-user satisfaction. Therefore, this research combines information systems success model DeLone and McLean (1992) and the technology acceptance model (TAM) Davis (1989) to prove the end-user satisfaction Debtor Information System. The object of the research is a financial institution 
under the supervision of Bank Indonesia Region Kediri.

\section{HYPOTHESIS DEVELOPMENT}

Quality Information Systems, Perceived Usefulness, Perceived Ease of Use and End User Satisfaction

An accounting information system has a good quality would give the perception of usability for the user. Because the system is useful for users, can benefit through the use of systems (Seddon, 1997). A good reliable system that allows users to carry out the work. A quality system will provide benefits to users, so users feel comfortable in doing work. Istianingsih and Wijanto (2008) and Kartika, et al (2016) agreed with the results of Seddon (1997). Shih (2004) conducted research on the quality of information systems to the perceived ease of use; show results by providing a secure Web system to consumers or lower access costs can improve the perception of the usefulness and ease of online trading will indirectly increase the acceptance of e-shopping to create a positive attitude. In line with the research conducted by Ali and Younes (2013) about the success of information systems in Tunisia explaining the impact of information quality by usefulness is felt to be slightly stronger than through perceived ease of use. DeLone and McLean (1992) explains that the higher the quality of the presented information system, will further improve user satisfaction. In line with Istianingsih and Wijanto (2008) and Kartika, et al (2016), and Saleh, et al (2012) which state that the quality of information systems has a positive effect on user satisfaction accounting software; to provide information needed by all users, both internal and external so that users can feel satisfaction with the system used. Unlike Seddon (1997) who revealed the results of his research that a person would not feel satisfied with the system used, if the system has long been used without development.

$\mathrm{H}_{1}$ : Quality of information systems affect the perception of usefulness.

$\mathrm{H}_{2}$ : Quality of information systems affect the perceived ease of use.

$\mathrm{H}_{3}$ : Quality of information systems affect the enduser satisfaction.

Quality of Information, Perceived Usefulness, Perceived Ease of Use and End User Satisfaction

Istianingsih and Wijanto (2008) conducted a study by examining the effect of quality information and perceived usefulness. The results of the study indicate that the higher the quality of information produced by the accounting software used, will increase the perceived usefulness seen from the user's perception. Information provided by the system shall have a validity that is relevant to help carry out the task. Information must also have high accuracy. So that information can be said to be qualified as an impact that is useful for the user. The results of these studies are in line with Ali and Younes (2013) and Kartika, et al (2016).

DeLone and McLean (1992) in the preparation of the basic constructs of information system success reveals that the higher the quality of information produced an information system, can improve user satisfaction. End-user satisfaction pays attention to the content of the information provided by the system. Information will be qualified if the user obtain information easily and information can be used by the user. Thus satisfaction will be felt by the user. This has received positive support from various researchers such as Seddon (1997), Istianingsih and Wiijanto (2008), Saleh, et al (2012), and Ali and Younes (2013).

$\mathrm{H}_{4}$ : The quality of information affects the perception of usability.

$\mathrm{H}_{5}$ : The quality of information affects the perceived ease of use.

$\mathrm{H}_{6}$ : Quality of information has an effect on enduser satisfaction.

\section{Perceived Usefulness and Perceived Ease of Use}

Davis (1989) argues perceived ease hypothesized to have a significant direct effect on perceived usefulness. Easy to use system produces improved job performance for the user. The information system is easy to use by users because the system is easily accessible to users. Users easily get the information needed when accessing the system. The information provided can be rearranged according to user demand. User information will be used to report the results of data processing of the information. Davis (1989) as the inventor of the TAM construct received support for his research by several researchers namely Adam, et al (1992), Shih (2004), and Santoso (2012).

$\mathrm{H}_{7}$ : Perceptions of ease of use affect the perception of usability. 


\section{Perceived Usefulness, Perceived Ease of Use and End User Satisfaction}

Lee and Jun (2007) conducted a study with the object of m-commerce users in South Korea to test the effect of perceptions of usability on enduser satisfaction. These results explain that the perceived usefulness positively affects user satisfaction. The information system is considered easy to use refers to the extent to which users trust the information system. The use of the system can provide ease of use which is felt to affect user behavior, both directly and indirectly. This behavior can provide benefits that the user will feel satisfaction using the information systems and services provided. The results of the study are in line with those conducted by Istianingsih and Wijanto (2008) and Amin, et al (2014) which showed a positive influence on perceived usefulness towards user satisfaction of accounting software.

Lee and Jun (2007) revealed that perceptions of high ease of use can affect user satisfaction in using the system. In line with the research conducted by Amin et al. (2014) with operating system user objects on mobile or mobile in Singapore which shows that the perception of ease of use for mobile user satisfaction explains the high trust in ease of use influenced by the ease of using a mobile site. Based on the above description of this study hypothesized as follows:

$\mathrm{H}_{8}$ : Usage perceptions affect end-user satisfaction.

$\mathrm{H}_{9}$ : Perception of ease of use has an effect on enduser satisfaction.

\section{DATA DAN METHODS}

This research uses primary data, to get the primary data by the researcher, the survey method will be used by giving a set of questionnaires related to variables. Respondents were asked to give responses to the contents of the questionnaire in accordance with the circumstances felt or experienced by the respondent. The researcher will use a Likert Scale approach with six gradations of cue, from the lowest score (ie 1) to the highest score (ie 5). The research proposed uses a sampling technique that is Non Probability Sampling with Purposive Sampling method. Non-probability sampling technique is a sampling technique from an unknown population or is without sampling frame.

From the results of sampling of financial institutions, a population of 240 financial institutions. Then financial institutions that were not willing to be collected were found to be 218 financial institutions. So that researchers get a sample of 22 finan- cial institutions. So that from the criteria obtained the number of respondents was 186 respondents. The data analysis technique used in this study is Structural Equation Modeling (SEM), with the test equipment used is the software version 3.0 SmartPLS. In SEM for a minimum sample size is 10 times the research path (Abdillah and Hartono, 2015).

\section{RESULTS}

\section{Validity Testing Outer Model}

The value of the loading factor is considered valid if it has an outer loading value of $>0.7$, but for the scale of research the value of outer loading $>0.5$ is considered practically significant, while the value of Average Variance Extracted (AVE) can be valid if AVE $>0.5$ (Table 1). The PLS output results obtained by the outer loading value shown in figure 1.

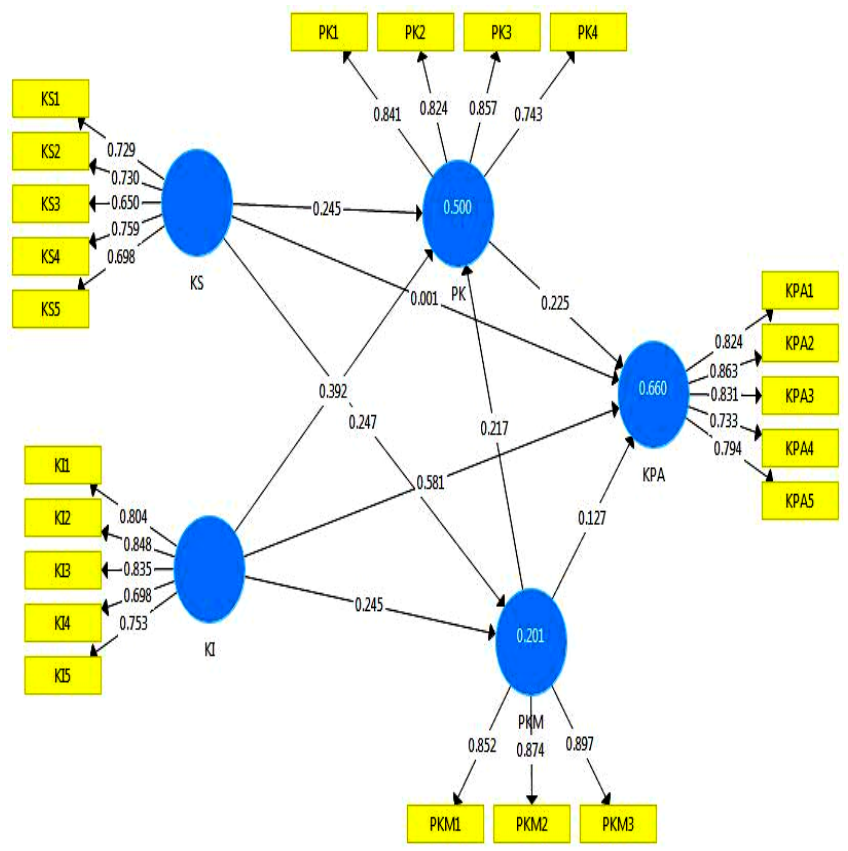

Figure 1. Test Results for Convergent Validity Source: Results of PLS output, 2018

\section{Reliability Testing}

In the reliability testing, the researchers conducted two methods by looking at the value of Cronbach's Alpha and Composite Reliability. In testing Cronbach's Alpha said to be reliable if the Cronbach's Alpha value of a variable has a value above 0.6. As for testing the Composite Reliability 
said to be reliable if the value of the variable measuring above 0.7 .

Table 1. Output of PLS Outer Loading and AVE

\begin{tabular}{|c|c|c|c|}
\hline Variable & Indicator & $\begin{array}{l}\text { Outer } \\
\text { Loading }\end{array}$ & AVE \\
\hline \multirow[t]{6}{*}{ Information Quality (KI) } & & & 0.623 \\
\hline & KI1 & 0.804 & \\
\hline & $\mathrm{KI} 2$ & 0.848 & \\
\hline & $\mathrm{KI} 3$ & 0.835 & \\
\hline & KI4 & 0.698 & \\
\hline & KI5 & 0.753 & \\
\hline \multirow[t]{6}{*}{ End User Satisfaction (KPA) } & & & 0,656 \\
\hline & KPA1 & 0.824 & \\
\hline & KPA 2 & 0.863 & \\
\hline & KPA 3 & 0.831 & \\
\hline & KРA 4 & 0.733 & \\
\hline & KPA 5 & 0.794 & \\
\hline \multirow{6}{*}{$\begin{array}{l}\text { Quality of information sys- } \\
\text { tems (KS) }\end{array}$} & & & 0.510 \\
\hline & KS1 & 0.729 & \\
\hline & KS2 & 0.730 & \\
\hline & KS3 & 0.650 & \\
\hline & KS4 & 0.759 & \\
\hline & KS5 & 0.698 & \\
\hline \multirow[t]{5}{*}{ Usage Perception (PK) } & & & 0,668 \\
\hline & PK1 & 0.841 & \\
\hline & PK2 & 0.824 & \\
\hline & PK3 & 0.857 & \\
\hline & PK4 & 0.743 & \\
\hline \multirow{5}{*}{$\begin{array}{l}\text { Perception of Ease of Use } \\
(\mathrm{PKM})\end{array}$} & & & 0.668 \\
\hline & PKM1 & 0.841 & \\
\hline & PKM2 & 0.824 & \\
\hline & PKM3 & 0.857 & \\
\hline & PKM4 & 0.743 & \\
\hline
\end{tabular}

Table 2. Output Cronbach's Alpha dan Composite Reliability

\begin{tabular}{lll}
\hline Variable & $\begin{array}{l}\text { Cronbach's } \\
\text { Alpha }\end{array}$ & $\begin{array}{l}\text { Composite } \\
\text { Reliability }\end{array}$ \\
\hline Information Quality (KI) & 0.848 & 0.892 \\
End User Satisfaction (KPA) & 0.868 & 0.905 \\
Quality of information systems (KS) & 0.760 & 0.839 \\
Usage Perception (PK) & 0.834 & 0.889 \\
Perception of Ease of Use (PKM) & 0.846 & 0.907 \\
\hline Source : Processed PLS Output, 2018 & &
\end{tabular}

Based on Table 2 in mind that the value of Cronbach's Alpha has reached a value above 0.6. Whereas the Composite Reliability testing indicated that all variables that researchers have reached above the value of 0.7 . Based on the table it can be stated that the variables used by researchers have met reliability; the variables used by researchers have been consistent, accurate and stated reliably.

R-Square is used to measure the ability of a model to explain variations in the dependent variable. R-square value is used as a measurement of the degree of variation change of the independent variable on the dependent variable. Tests that have been done produce the R-Square value shown in table 3.

Table 3. Output R-Square

\begin{tabular}{ll}
\hline Variable & R-Square \\
\hline End User Satisfaction (KPA) & 0.660 \\
Usage Perception (PK) & 0.500 \\
Perception of Ease of Use (PKM) & 0.201 \\
\hline Source : Processed PLS Output, 2018 &
\end{tabular}

Table 3 shows that the End User Satisfaction variable (KPA) has a R-Square value of 0.660 which means that the Information System Quality, Information Quality, Perception Usability and Ease of Use variables have been able to explain $66 \%$ of changes in the End User Satisfaction variable and the remaining $34 \%$ are affected by other factors outside the research model.

Usability Perception Variable (PK) has a value of R-Square of 0.500 which means that the variable Information System Quality, Information Quality and Ease of Perception can explain as much as $50 \%$ of changes in the variable Perception of Use and the remaining $50 \%$ is influenced by other factors.

Tabel 4. Analysis Results

\begin{tabular}{llllll}
\hline Variable & $\mathrm{O}$ & $\mathrm{M}$ & $\begin{array}{l}\text { St. } \\
\text { Dev. }\end{array}$ & t Statistic & $\begin{array}{l}\mathrm{P} \\
\text { Value }\end{array}$ \\
\hline $\mathrm{KI} \rightarrow \mathrm{KPA}$ & 0.581 & 0.580 & 0.068 & 8.496 & 0.000 \\
$\mathrm{KI} \rightarrow \mathrm{PK}$ & 0.392 & 0.391 & 0.110 & 5.249 & 0.000 \\
$\mathrm{KI} \rightarrow \mathrm{PKM}$ & 0.245 & 0.239 & 0.074 & 2.232 & 0.026 \\
$\mathrm{KS} \rightarrow \mathrm{KPA}$ & 0.001 & 0.001 & 0.110 & 0.009 & 0.993 \\
$\mathrm{KS} \rightarrow \mathrm{PK}$ & 0.245 & 0.249 & 0.086 & 2,835 & 0.005 \\
$\mathrm{KS} \rightarrow \mathrm{PKM}$ & 0.247 & 0.253 & 0.093 & 2.667 & 0.008 \\
$\mathrm{PK} \rightarrow \mathrm{KPA}$ & 0.225 & 0.229 & 0.073 & 3.062 & 0.002 \\
$\mathrm{PKM} \rightarrow \mathrm{KPA}$ & 0.127 & 0.127 & 0.059 & 2.176 & 0.030 \\
$\mathrm{PKM} \rightarrow \mathrm{PK}$ & 0.217 & 0.214 & 0.071 & 3.042 & 0.002 \\
\hline O=Original Sample; M Means Sample & & \\
Source : Processed PLS Output, 2018 & &
\end{tabular}

The Ease of Use Perception Variable (PKM) has an R-Square value of 0.201 , which means that the Information System Quality and Information Quality variable is only able to explain $20.1 \%$ of the change in Ease of Use Perception variable and the remaining $79.9 \%$ is influenced by other factors outside the research model. The value of R-Square is found in the variable Ease of Perception to Use (PKM) which shows $20.1 \%$ because for variables such as satisfaction it is very difficult to get a large R-Square value. This is in line with Hair et al (2013) stating that there are no basic rules of practical rules for the value of R-Square that can be accepted in research, because it all depends on the level of complexity of the research model. R-Square value of 0.2 or $20 \%$ is considered high in the context of 
behavioral research to show satisfaction. Because this study uses behavioral variables, namely Ease of Perception to Use (PKM) with a R-Square value of 0.201 , it is considered high that it meets 20.1\% which shows End User Satisfaction (KPA).

\section{Hypothesis Testing}

Testing $\mathrm{t}$ statistics done by using $\mathrm{t}$-test and $\mathrm{P}$ value. If the value of $P$ value less than 0.05 means significant testing, and vice versa if the $P$ value is greater 0.05, not significant; and use the two tailed hypothesis so that the t-statistic value must be greater than 1,960 (Table 4).

\section{DISCUSSION}

The results of the study indicate that Quality Information System has a positive effect on Perception of Use. The quality of the information system shows how well the ability of an information system to provide user information needs. The quality of a good information system is related to the reliability and availability of equipment, ease of use, and response time is a determining factor why an information system is used or not used. So that the better the quality of the information system, it will be able to meet user needs. The better the quality of the information system, the better the quality of the information system and the quality of information. This will have a positive impact on the user

The results of this study are in line with the research of DeLone and McLean (1992), Seddon (1997), Istianingsih and Wijanto (2008), Ali and Younes (2013), and Kartika, et al (2016) which state that Information System Quality has a positive effect on Perception of Use.

The results of the study indicate the quality of information system positively affects Perceived Ease of Use. The ease of use is one indicator of the quality of information systems. As for the good quality of the information system, it will tend to provide convenience for users. So that the quality of the information system that is getting better, a financial institution will tend to provide convenience for its customers. The results are consistent with research Shih (2004) and Ali and Younes (2013) which states that the quality of information system positively affects Perceived Ease of Use.

The results of the study show the Quality of Information Systems does not affect the End User Satisfaction. The results of this study are not in line with DeLone and McLean (1992), Istianingsih and Wijanto (2008), Saleh, et al (2012), Ali and Younes (2013), and Kartika, et al (2016) which state Infor- mation System Quality has a positive effect on Satisfaction Last user. The results of the study confirm the criticism made by Seddon (1997) and Kumala (2015) which stated that Information System Quality has no positive effect on End User Satisfaction. The results of this study also confirm the existence of Contingency Theory which states that the design of the system and its use depends on the arrangement of the information system designer where the control is operated, must consider the existence of environmental uncertainty, to design and implement an accounting system that provides information to facilitate decision making (Istanti, 2013; Susanto, 2012).

The results of study is the quality of information influences the perception of usefulness. The results of this study confirm the research conducted by Istianingsih and Wijanto (2008), Ali and Younes (2013), and Kartika, et al (2016). The study states that the quality of information affects the perception of usability. Where more information is produced by quality information systems, it can be said that the information provides benefits to its users. The results of this study are not in line with the reason for being replaced by SID with SLIK which states that SID information data is not in accordance with the actual condition of the debtor. Because from the results of this study it can be seen that SID is able to provide accurate and relevant data information (okezone.com, 2017). Hypothesis 5 in this study is the effect of Information Quality Of Perceived Ease of Use. From the above data shows the value of the path coefficient of 0,244 with $t$ value of 2.232 or positive value greater than $t$ table (1.960) and $0.026 \mathrm{p}$ value less than 0.05 . Then hypothesis 5 is accepted. This study confirms the research conducted by Shih (2004), and Ali and Younes (2013). The study states that quality information affects the perception of ease of use for the information presented.

The results of the study indicate that the effect of Information Quality is End-User Satisfaction. This study confirms research by Seddon (1997), Istianingsih and Wiijanto (2008), Saleh, et al (2012), and Ali and Younes (2013). The study found that the quality of information influence on end-user satisfaction. But the results of this study are not in line with the research conducted by Kumala, et al (2015) and Kartika, et al (2016) which states that quality information cannot provide satisfaction for the user, and the reason for replacing SID to SLIK which states SID information is less valid the condition of the actual debtor (okezone.com, 2017).

The results of the study indicate that the per- 
ception Perceived Ease of Use Against utilities. The results of this study confirm the research conducted by Davis (1989), Adam, et al (1992), Shih (2004), and Santoso (2012). The study states that someone who has a perception using the information system is easy, so the user will believe in using information systems because the information system is useful for his work.

The study found that perceptions of usefulness can affect end-user satisfaction on the use of information systems. The results of this study confirm the research of Lee and Jun (2007), Istianingsih and Wijanto (2008), Amin, et al (2014), and Kartika, et al (2016).

The study found that the perceived ease of use can improve upon the satisfaction of the end user. The perceived ease of use is easy and in accordance with what the user needs, will tend to have a positive impact on the level of user satisfaction. Easy information system, tends to be shorter time needed by users. The results of this study confirm the research Lee and Jun (2007) and Amin, et al (2014) which states that the perceived ease of use can improve upon the satisfaction of the end user. It shows that by using the information system, easy to use user believe that then feel satisfaction when using the information system.

\section{CONCLUSION AND SUGGESTION}

This research has tested and proved that the quality of information systems has a significant positive effect on perceived usefulness, perceived ease of use, and no significant positive effect on End User Satisfaction. It shows that the SID as a quality system are usability and ease of use not to give satisfaction to the users. While the Information Quality positive significant effect on the perception of usefulness, Perceived Ease and End User Satisfaction.

The test results indicate that the perception Ease Using a positive significant effect on the perception of usefulness and End User Satisfaction. This shows that the higher the ease of users using SID can increase trust by relying on SID can be useful to increase productivity and user performance in completing their work. Perception of Use has a significant positive effect on. This shows that the higher the user's trust in the use of SID the more satisfied the user relies on SID. While the Ease of Perception of Use has a significant positive effect on End User Satisfaction. This shows that SID is able to present output that is easy to use so that users feel satisfied using the system.
Limitations of this study include the stretcher just focusing on one object SID so the impact on the results of research SID mismatch and the replacement becomes SLIK reason; not using the construct of the updated DeLone and McLean Information System Success Model (2014) using the construct of Service Quality and Intention to Use; and the amount of financial institutions in each city/county and the number of respondents in each financial institution has a high enough margin. It is difficult for researchers to look at the impact of variables influence each financial institution of questionnaires collected. And Determination of the number of respondents should be balanced between financial institutions or organizations with one another, so as to facilitate and increase accuracy in the analysis of differences in the influence of variables in each financial institution or organization.

\section{REFFERENCE}

Abdillah, W., dan Hartono, J. (2015). Partial Least Square (PLS) Alternatif Structural Equational Modeling (SEM) dalam Penelitian Bisnis. Edisi 1. Yogyakarta: Penerbit Andi.

Adams, D.A., Nelson, R. Ryan., dan Todd, Peter A. (1992). Perceived Usefulness, Ease of Use, and Usage of Information Technology: A Replication. Management Information Systems Research Center. Pp. 227-247.

Ajzen, Idan Fishbein, M. (1980). Belief, Attitude, Intentions and Behavior: An Introduction to Theory and Research. Boston: Addison-Wesely.

Ajzen, I. (1988). Attitudes, Personality, and Behavior. Chicago : Dorsey Press

Ajzen, I. (1991). The Teory of Planned Behavior. Organizational Behavior and Human Decision Process. Vol. 50: 179-211.

Ajzen, I. (2001). Attitudes, Traits, and Actions : Dispotional Prediction of Behavior in Personality and Social Psychology. Advances in Experimental Social Psychology. Vol. 20: 1-63.

Ajzen, I. (2002). Perceived Behavioral Control, SelfEfficacy, Locus of Control, and the Theory of Planned Behavior. Journal of Applied Social Psychology. Vol. 32: 665-683.

Ali, B. M., dan Younes, B., (2013). The Impact of Information Systems on user Performance: An Exploratory Study. Journal of Knowledge Management, Economics and Information Technology.

Amin, M., Rezaei, S., and Abolghasemi, M., (2014). 
User Satisfaction with mobile website: the impact of perceived usefulness (PU), perceived ease of use (PEOU) and Trust. Nankai Bussiness Review International. Vol. 5 (3): 258274.

Budi, S. S., (2016). Persepsi Pengguna terhadap Kemanfaatan dan Kemudahan Penggunaan Aplikasi Sistem Informasi Baru (Studi Kasus di Sekolah Tinggi Ilmu Ekonomi SBI Yogyakarta). Jurnal Bisnis Manajemen dan Akuntansi. STIE SBI Yogyakarta. Vol. 3(1): 1-18.

Conner, M., dan Armitage, C. J. (1998). Extending the Theory of Planner Behavior: A Review and Avenues for Further Research. Journal of Applied Social Psychology. Vol. 28(15): 14291464.

Davis, Fred D. (1989). Perceived Usefulness, Perceived Ease Of Use, And User Acceptance of Information Technology. Management Information Systems Research Center.: 319-340.

DeLone, W. H., and McLean, E.R., (1992). Information System Success: The Quest for the Dependent Variable. Journal. Information System Research.: 60-95.

DeLone, W. H., dan McLean, Ephraim R. (2003). The DeLone and McLean Model of Information System Success: A Ten Year Update. Journal Information System Research. Vol. 19(4): 9-30.

DeLone, W. H., McLean, Ephraim R., dan Petter, Stacie. (2013). Information Systems Success: The Quest for the Independent Variables. Journal of Management Information Systems. Vol. 29(4): 7-61.

Doll, W. J., dan Torkzadeh, Gholamreza. (1988). The Measurement of End-User Computing Satisfaction. Management Information Systems Research Center. University of Minnesota. Vol. 12(2): 259-274.

Fendini, D. S.., Kertahadi., dan Riyadi. (2013). Pengaruh Kualitas Sistem dan Kualitas Informasi terhadap Kepuasan Pengguna (Survei pada Karyawan Pengguna Aplikasi Pelayanan Pelanggan Terpusat (AP2T) di PT PLN (Persero) Area Malang). Jurnal Administrasi dan Bisnis. Universitas Brawijaya.

Gozhali, I., (2011). Analisis Multivariate SPSS. Semarang: Badan Penerbit Fakultas Ekonomi dan Bisnis Universitas Diponegoro.

Hair, J. F., Hult, G., Thomas M., Ringle, Christian M., and Sarsted, M., (2013). A Primer on Partial Least Squares Structural Equation Modeling (PLS-SEM). London : SAGE Publications, Inc.

Hartono, J. (2007). Model Kesuksesan Sistem Teknologi
Informasi. Yogyakarta : Penerbit Andi.

Hartono, J. (2007). Sistem Informasi Keperilakuan. Yogyakarta : Penerbit Andi

Hersusdadikawati, E., (2005). Pengaruh Kepuasan atas Gaji terhadap Keinginan untuk Berpindah Kerja, dengan Komitmen Organisasional sebagai Variabel Intervening (Studi Empiris pada Dosen Akuntansi Perguruan Tinggi Swasta Jawa Tengah). Jurnal Studi Manajemen dan Organisasi. Universitas Diponegoro Semarang. Vol. 2(1): 86-110.

Hussein, S.A., (2015). Penelitian Bisnis dan Manajemen Menggunakan Partial Least Square (PLS) dengan smartPLS 3.0. Modul Ajar Jurusan Manajemen, Fakultas Ekonomi dan Bisnis. Universitas Brawijaya.

Istanti, Sri Layla Wahyu. (2013). Teori Kontigensi, Sistem Pengendalian Manajemen dan Keluaran Perusahaan: Hasil yang Lalu dan Arah Masa Depan. ISSN 1829-7978. Rembang: STIE YPPI Rembang

Istianingsih dan Wijanto, S. H., (2008). Pengaruh Kualitas Sistem Informasi, Perceived Usefulness, dan Kualitas Informasi terhadap Kepuasan Pengguna Akhir Software Akuntansi. Simponsium Nasional Akuntansi XI Pontianak.

Istianingsih. (2009). Pengaruh Kepuasan Pengguna Sistem Informasi terhadap Kinerja Individu (Studi Empiris pada Pengguna Paket Program Aplikasi Sistem Informasi Akuntansi di Indonesia). Skripsi. Jakarta. Universitas Mercu Buana.

Jaya, I Gede Nyoman Mindra., dan Sumertajaya, I Made. (2008). Pemodelan Persamaan Struktural dengan Partial Least Square. Semnas Matematika dan Pendidikan Matematika.

Kartika, N.D., Anton., dan Adnanti, W.A., (2016). Analisis Kualitas Sistem Informasi, Perceived Usefulness dan Kualitas Informasi Terhadap Kepuasan End User Software Akuntansi. Simposium Nasional Akuntansi XIX Lampung.

Kim, S., dan McHaney, R., (2000). Validation of the End-User Computing Satisfaction Instrument in Case Tool Environments. Journal of Computer Information System: 49-55.

Kumala, R.A., (2015). The Impact of Information Quality and System Quality on User Satisfaction in Web-Based Information System (Study on the Employees of Bank Rakyat Indonesia Malang). Jurnal Administrasi Bisnis. Universitas Brawijaya. Vol. 2(2): 1-12.

Kurniawan, D., Semuel, H., dan Japarianto, E. 
(2013). Analisis Penerimaan Nasabah terhadap Layanan Moobile Banking dengan Menggunakan Pendekatan Technology Acceptance Model dan Theory of Reasoned Action. Vol. 1(1): 1-13.

Lee, T.M., and Jun, J.K., (2007). Contextual Perceived Value?: Investigating the Role of Contextual Marketing for Customer Relationship Management in a Mobile Commerce Context. Business Process Management Journal. Vol. 13(6): 798-814.

Lubis, A. I., (2010). Akuntansi Keperilakuan. Edisi 2. Jakarta: Salemba Empat.

Mahmudah, H. (2013). Trade Off Relevance dan Reliability: Isu IFRS. Jurnal Riset Akuntansi. Universitas Islam Malang. Vol. 4(2): 84-89.

Manansal, A.A., (2013). Kecerdasan Emosi Mahasiswa Akuntansi Fakultas Ekonomi dan Bisnis pengaruhnya terhadap Tingkat Pemahaman Akuntansi. Jurnal Riset Ekonomi, Manajemen Bisnis, dan Akuntansi. Vol. 1(3): 901910.

Mauludi, A. (2016). Teknik Belajar Statistika 2. Jakarta: Alim's Publishing.

Montazemi, A.R., (1988). Factors Affecting Information Satisfaction in the Context of the Small Business Environment. Management Information System Research Center. Vol. 12(2): 239-256.

Noviandini, N.C., (2012). Pengaruh Persepsi Kebermanfaatan, Persepsi Kemudahan Penggu-naan, dan Kepuasan Wajib Pajak terhadap Penggunaan E-Filling bagi Wajib Pajak di Yogyakarta. Jurnal Nominal. Vol. 1(1): 15-22.

Rahmawati, Y., dan Wijanto, S.H.,. (2012). Keberhasilan Implementasi Electronic Government Berdasarkan Persepsi Pengguna. Simposium Nasional Akuntansi XV Banjarmasin.

Rama, Dasaratha V., dan Jones, Frederick L. (2011). Sistem Informasi Akuntansi. Jakarta : Penerbit Salemba Empat.

Romney, Marshall B., dan Steinbart, P.J., (2014). Sistem Informasi Akuntansi. Jakarta: Penerbit Salemba Empat.

Revels, J., Tojib, D., dan Tsarenko, Y., (2010). Understanding consumer intention to use mobile services. Journal. Australian Marketing Journal: 74-80.

Sarstedt, M., Ringle, C.M.,. and Hair, Joseph F. (2017). Partial Least Square Structural Equation Modeling.

Saleh, T., Darwanis., dan Bakar., Usman. (2012).
Pengaruh Kualitas Sistem Informasi Terhadap Kualitas Informasi Akuntansi dalam Upaya Meningkatkan Kepuasan Pengguna Software Akuntansi pada Pemerintah Aceh. Jurnal Akuntansi Pascasarjana Universitas Syah Kuala: 110-124.

Santoso, B. (2012). Pengaruh Perceived Usefullness, Perceived Ease of Use, dan Perceived Enjoyment terhadap Penerimaan Teknologi Informasi (Studi Empiris di Kabupaten Sragen). Jurnal Studi Akuntansi Indonesia. Universitas Sebelas Maret.

Sekundera, Charlesto P.L. (2006). Analisis Penerimaan Pengguna Akhir dengan Menggunakan Technology Acceptance Model dan End User Computing Satisfaction terhadap Penerapan Sistem Core Banking pada Bank ABC. Tesis. Semarang. Universitas Diponegoro.

Seddon, P. B., (1997). A Respecification and Extension of the DeLone and McLean Model of IS Success. Information System Research. Vol. 8(3): 240-253.

Shih, Hung-Pin. (2004). An empirical study on predicting user acceptance of e-shopping on the Web. Information and Management: 351-368.

Sholiha, E.U.N., dan Salamah, M., (2015). Structural Equational Modeling-Partial Least Square untuk Pemodelan Derajat Kesehatan Kabupaten/Kota di Jawa Timur (Studi Kasus Data Indeks Pembangunan Kesehatan Masyarakat Jawa Timur 2013). Jurnal Sains dan Seni. Vol. 4(2): 169-174.

Suardhika, I Made Sadha., Sutrisno., Sukoharsono, E.G., dan Purnomosidhi, B., (2012). Pengaruh Implementasi Budaya Tri Hita Karana terhadap Penggunaan Sistem informasi Akuntansi dimediasi keyakinan diri atas komputer, keinovatifan personal, persepsi kegunaan dan persepsi kemudahan penggunaan pada Bank Perkreditan Rakyat di Bali. Simposium Nasional Akuntansi XV Banjarmasin.

Suhendro. (2009). Pengaruh Perceived Usefulness dan Perceived Ease of Use dalam Penggunaan Sistem Informasi Keuangan Daerah. Tesis. Surakarta. Universitas Sebelas Maret.

Sugiyono, (2015). Statistika untuk Penelitian. Bandung: Penerbit Alfabeta

Susanto, Y.K., (2012). Pendekatan Kontijensi dalam Penelitian Informasi Sistem Akuntansi Managemen. Media Bisnis: 27-33.

Suwardjono, (2014). Teori Akuntansi Perekayasaan Pelaporan Keuangan. Edisi Ketiga. Cetakan 
Keempat. Yogyakarta: BPFE Universitas Gadjah Mada

Wibowo, S.F., Rosmauli, D., dan Suhud, U., (2015). Pengaruh Persepsi Manfaat, Persepsi Kemudahan, Fitur Layanan, dan Kepercayaan terhadap Minat Menggunakan E-Money Card (Studi pada Pengguna Jasa Commuterline di Jakarta). Jurnal Riset Manajemen Sains Indonesia. Vol. 6(15): 441-456. 